\title{
Media Literacy Profiles of Biology Pre-Service Teacher Candidates in the 21st Century in the Biology Education Departement, Universitas Muhammadiyah Purwokerto
}

\author{
Listika Yusi Risnani $^{1}$ \\ \{listikayusirisnani@ump.ac.id ${ }^{1}$ \} \\ Muhammadiyah University of Purwokerto, Jalan Ahmad Dahlan, Kembaran, Purwokerto 53182
}

\begin{abstract}
Prospective teachers are essential to have mastery of media literacy related to their teaching assignments, namely developing teaching materials and preparing learning media so that learning messages reach students effectively and efficiently. The purpose of this study was to determine the mastery of media literacy among biology teacher candidate students in the Biology Education Departement, FKIP UMP. This research was conducted in the even semester of the 2018/2019 academic year. The population of this study was students of the Biology Education Departement, FKIP, UMP. The sampling technique used was the purposive non-random sampling, namely all students in the final year (semester 8). Data collection methods are using questionnaires, interviews, and documentation studies. The questionnaire instrument used has been validated using content and construct validity by information technology experts. The results showed the ability to access, the average questionnaire score was 4.24 (good), and the interview results were in a good category. On the ability to analyze the media, the average questionnaire was $3.50-3.81$ (good), and the results of the interview were in a low category. On the ability to create media, the average questionnaire score was 2.85 - 3.34 (enough), and the results of the interview were in a good category. This study concludes that the mastery of media literacy in biology teacher candidate students in the Biology Education Departement is in the sufficient to good category.
\end{abstract}

Keywords: media literacy, 21st Century, students, a pre-service biology teacher

\section{Introduction}

The 21st Century is a century of globalization and openness characterized by the rapid development of information and communication technology that has influenced and changed various aspects of human life. Digital-based information technology is growing fast. Almost all instruments for research, professional work in various scientific fields have utilized digital technology, including computers, satellite communications, robotics, videotext, cable television, e-mail, electronic games, and electronic-based office machines. The world of life is increasingly connected with authentic information technology via the internet. The internet as a global network contains millions of websites, databases, and various information that allows someone to search, find, manipulate existing ones, create and disseminate new information so that a lot of useful and useless information is available on the internet. The development of internet culture and the Cyber Society that combines the internet with cellular communication 
with various hardware innovations have made the internet replace the communication model of social life and even change systems and cultural values and the human spiritual dimension [3]. This raises the main problem faced, namely how a person can get information appropriately and effectively. The ability to choose the right information as needed is more important than just how to get access to that information [12]. Finding appropriate and useful information is closely related to media literacy because data is stored and communicated through a medium.

In education, information and communication technology has been proven to merge the "space and time" factor, which has been an aspect determining the speed and success of mastery of science [3]. According to the Assessment and Teaching of 21st Century Skills (ATC21S), talent, information, and communication technology, the ability to learn and work through social media (digital) networks which are near related to media literacy, are considered skills for living in the world [8]. The same thing is also stated by Trilling \& Fadel (2009), which says that there are essential skills that must be mastered by students or students in the 21 st Century, one of which is media literacy [17]. Media literacy can understand various media types to communicate messages, choose the right media from several available options, and use the media to convey messages effectively [17]. Media literacy is essential to be controlled by student-teacher candidates considering the main task, namely teaching (transfer of knowledge). Before Teaching, teachers are required to make lesson plans, one of which is learning media. Media is a tool to convey messages or materials. In Primary and Secondary Education, information and communication technology (ICT) is one of the principles of learning to increase learning efficiency and effectiveness [9]. Prospective teachers need to have the media literacy to be able to create ICT-based media. Good mastery of media literacy will make it easier for future teachers to obtain various information that is increasingly open today. Speed, ease, and accuracy of getting information to develop teaching materials will only be accepted if prospective teachers have good media literacy skills. Future teachers who have media literacy are expected to create more meaningful and enjoyable learning. It is also hoped that it will transmit, teach, and print students later to have the same skills needed to be successful in life.

In general, media literacy is the key to mastery of other skills needed for a successful life in the 21 st Century, such as information literacy [19]. Besides, media literacy also plays a role in supporting problem-solving efforts and creating new knowledge as one of the keys to life's success in the 21st Century [14] [19].

this is a challenge for tertiary institutions, predominantly the Teacher Training Education Institution (LPTK), to produce qualified teacher graduates equipped with adequate media literacy skills. Mastery of literacy for prospective biology teacher-students is beneficial in studying and doing academic assignments. At the same time, they are still in college and useful when students enter the world of work and become teachers later. This is because the characteristics of the 21 st-century job sector prioritize information and knowledge rather than manufacturing services.

A preliminary study by observing students of the Biology Education study program in various generations shows that most students already have smartphones/gadgets and personal laptops, and internet access. However, many students have not utilized the internet optimally to support the learning process. They use the internet more for social networking and entertainment. Some students even complained that they did not have the source of information to complete the assigned assignments. Students take advantage of search engines such as Google to search for information, but most of them have not selected relevant and irrelevant information for reference. When doing studies and assignments, most students use connections or libraries that are less diverse and up to date. This can be seen in the year and the number of bibliographies and when students submit assignments, for example, making papers. Even in early semester 
students (semester 1 and 2), it is not uncommon for students to use references from high school books to study and organize assignments. Another finding is that students often use connections from sources that are not suitable as references. They cannot be accounted for legally, such as BlogSpot or WordPress, and rarely use research journals to learn and compile assignments. Another observed phenomenon was that during presentation assignments, both those who served as presenters and non-presenters almost always opened their smartphones to access information and used the information that appeared to ask or answer questions from discussion participants spontaneously without considering the correctness of the data. This indicates the lack of media literacy among students. The unavailability of information regarding information media literacy of Biology Education Departement students in UMP. In this study, an instrument will be developed to measure media literacy and explore the extent of mastery of media literacy in UMP Biology Education Departement students. The availability of information on media literacy for students is expected to become a reference and considerations for the Study Program in making policies related to learning and reference material in preparing learning designs by lecturers/teaching staff to improve the quality of learning.

The following are indicators used to explore data on mastery of media literacy in studentteacher candidates.

Table 1. Aspects and Indicators of Media Literacy

\begin{tabular}{cl}
\hline \multicolumn{1}{c}{ Aspects } & \multicolumn{1}{c}{ Indicators } \\
\hline Access media & Students can search, obtain, and collect information using the media. \\
Analyze media & $\begin{array}{l}\text { Students can understand the purpose of using media. } \\
\text { Students can test the correctness of different messages in the media. } \\
\text { Students can understand the values and perspectives of the media. } \\
\text { Students can understand the influence of the media on beliefs and } \\
\text { behavior. } \\
\text { Students can interpret media messages. } \\
\text { Students can apply a fundamental understanding of ethical and legal } \\
\text { issues when accessing and using media. } \\
\text { Students can understand and take advantage of the appropriate media } \\
\text { creation tools, characteristics, and conventions. } \\
\text { Students can create media effectively as the most appropriate } \\
\text { expression and interpretation in a multicultural/diverse environment. }\end{array}$ \\
\hline
\end{tabular}

\section{Method}

This study used a survey research design. The research was conducted in February-June 2019 for the 2018/2019 academic year. This study's sample was 8th-semester students (27 students) in the Biology Education Study Program, FKIP Muhammadiyah University of Purwokerto. The model was taken using a purposive non-random sampling technique considering that the 8th semester was students who had almost taken all courses that were considered representative to be taken data to provide input for improving the implementation of learning in the Study Program. Besides, 8th-semester students have taken instructional media courses, and some students have taken multimedia learning options that are considered closely related to media literacy skills.

The data collection technique uses non-test techniques, namely using questionnaires, interviews, and documentation studies. Distribution of questionnaires using a questionnaire 
instrument is used to explore information on mastery of media literacy in student-teacher candidates. The questionnaire consisted of 72 statement items compiled using a Likert scale (scale five), namely strongly agree (SS), agree (S), neutral (N), disagree (2), and disagree (TS). Before the questionnaire was used to explore data about the media, validation tests were carried out, namely content validation, construction validation by media and IT experts, namely one of the lecturers from the UMP Information Technology (IT) Study Program. Interview techniques and documentation studies were carried out to obtain more detailed information about media literacy according to the questionnaire's answers.

The data analysis technique used is the descriptive quantitative analysis and qualitative descriptive analysis. The quantitative descriptive approach was used to analyze the questionnaire's data about the students' mastery of media literacy. The data analysis steps are 1) questionnaire scoring, namely by changing the results of the questionnaire that is qualitative to be quantitative. The scoring guidelines for each item are $\mathrm{SS}=5 ; \mathrm{S}=4 ; \mathrm{N}=3 ; \mathrm{KS}=2 ; \mathrm{TS}=1$; 2) calculate the average score of each item according to the media literacy indicator; 3 ) determine the average score on each statement item based on the assessment criteria guidelines as follows.

Table 2. The Assessment Criteria

\begin{tabular}{ll}
\hline Value interval & Criteria \\
\hline $\mathrm{Mi}+1,5 \mathrm{Sbi}<\mathrm{X}$ & Very Good \\
$\mathrm{Mi}+0,5 \mathrm{Sbi}<\mathrm{X} \leq \mathrm{Mi}+1,5 \mathrm{Sbi}$ & Good \\
$\mathrm{Mi}-0,5 \mathrm{Sbi}<\mathrm{X} \leq \mathrm{Mi}+0,5 \mathrm{Sbi}$ & Enough \\
$\mathrm{Mi}-1,5 \mathrm{Sbi}<\mathrm{X} \leq \mathrm{Mi}-0,5 \mathrm{Sbi}$ & Not good \\
$\mathrm{X} \leq \mathrm{Mi}-0,5 \mathrm{Sbi}$ & Not good \\
\hline & Source $:[11]$
\end{tabular}

Information :

$\mathrm{X}$ : actual average score

Mi: The ideal mean

Sbi: ideal standard deviation

Mi: (highest ideal score + lowest perfect score)

Sbi: (highest ideal score - lowest perfect score)

Descriptive qualitative data analysis is presented in the form of descriptions used to analyze the results of interviews and documentation studies on information media literacy at the time of learning.

\section{Result and Discussion}

The results showed that the media literacy of biology teacher candidate students was in a suitable category with an average score of 3.47 with a standard deviation of 0.68 . The standard deviation is quite large, indicating that students' media literacy is controlled unevenly or uniformly. The details of the research results on each part of media literacy, namely the average score on the part of accessing media are 4.24 (very good) with a standard deviation of 0.24 , the average score for the aspect of analyzing media is 3.63 (good) with a standard deviation of 0.58 and the average score for the element of creating media is 3.20 (sufficient) with a standard deviation of 0.71 (Fig. 1) 


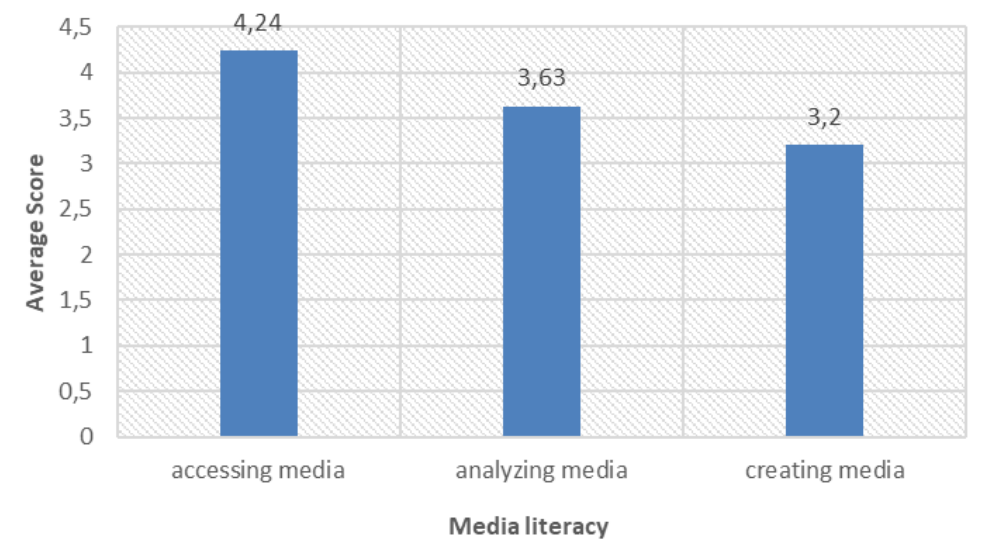

Fig. 1. Average of Score of Media Literacy from Questionnaire Results

The average score for the ability to access media is 4.24 (very good), the average score for the ability to understand media objectives is 3.62 (good), the average score for the ability to understand media understand the purpose of the media is 3.62 (good), the average score for the ability to test the truth of media messages is 3.63 (good), the average score for the ability to understand the value and the media point of view is 3.56 (good), moderate - The average score for the ability to understand the influence of media is 3.50 (good), the average score for the ability to interpret media messages is 3.64 (good), the average score for the application of ethics and law of media access is 3.81 (good), the average score for the ability to use tools for media creation is 3.34 (good), and the average score for the ability to create media is 2.85 (sufficient; Figure 2).

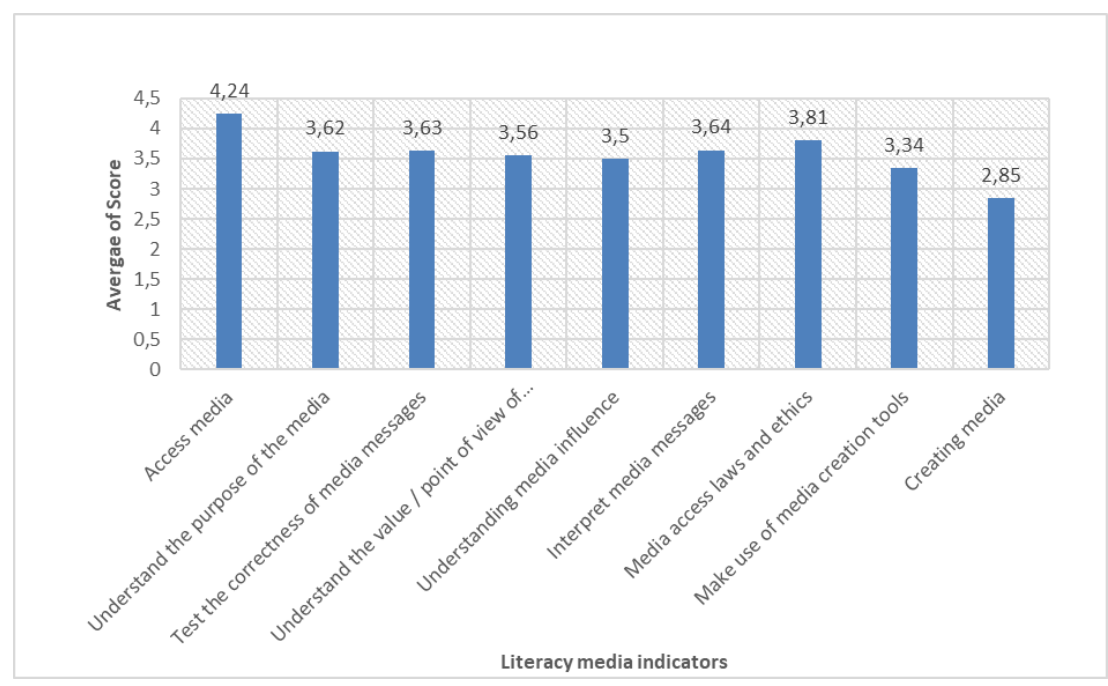

Fig.2. Average Score on Each Media Literacy Indicator 
Research on media ownership shows that biology teacher candidate students have media ranging from 8 to 19 media. 100\% of students have their laptops and smartphones. The details are smartphones, laptops, and WhatsApps social media owned by all students (100\%), television media, Instagram social media accounts, and Youtube accounts owned by $92.31 \%$ of students, Facebook accounts are owned by $84.62 \%$ of students, and media online shopping and online motorcycle taxi applications such as Share It, Shoope and Gojek are owned by approximately $53.85-73.08 \%$ of students. Apart from the top ten media owned by students, there are other media such as magazines, newspapers, radio, and various social media and other applications such as Blackberry Messenger (BBM), Twitter, skype, line, kaskus, grab with varying ownership, namely $7.59-38.46 \%$ of students (Figure 3 )

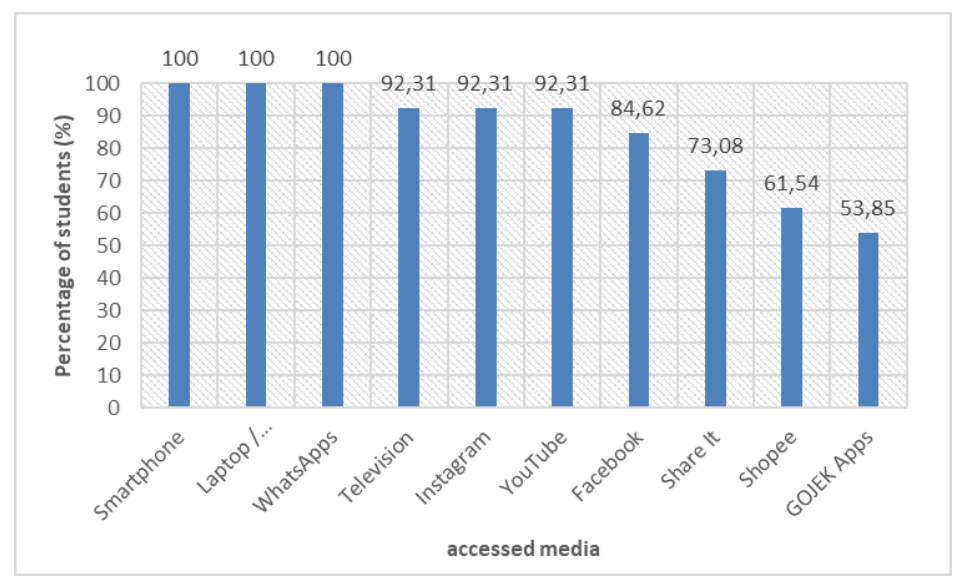

Fig. 3. Top Ten Media Owned by Students

The results showed that prospective teachers accessed media with various purposes, namely learning resources related to fulfilling coursework (100\%), means of communication, entertainment, searching for news, updating status (92.59-96.30\%), uploading photos ( $88.89 \%)$, means of discussion and brainstorming $(81.48 \%)$, looking for culinary references and means of buying and selling $(66.67-74.07 \%)$ and designing graphics, making videos and providing comments (40.74\%). Other purposes of accessing the media are writing blogs or journals, preserving local culture, and promoting (Figure 4). 


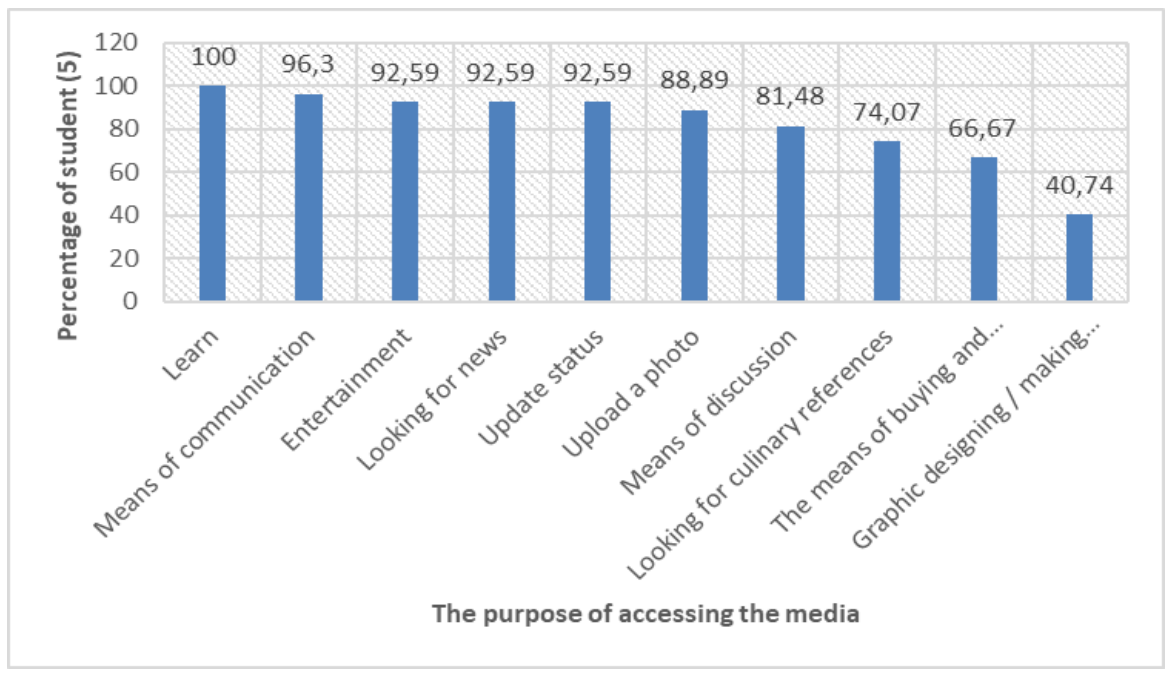

Fig. 4. The purpose of accessing the media by students

The results of interviews conducted with students to measure media literacy mastery are as follows.

Table 3. Results of Interviews and Documentation Studies on Mastery of Media Literacy

\begin{tabular}{|c|c|c|}
\hline Aspect & Indicator & Description \\
\hline $\begin{array}{l}\text { Accessing } \\
\text { media }\end{array}$ & $\begin{array}{l}\text { We are seeking, } \\
\text { obtaining, and gathering } \\
\text { information using the } \\
\text { media. }\end{array}$ & $\begin{array}{l}\text { All students (100\%) have been able to search for and collect } \\
\text { information from various media. All students stated that most } \\
\text { often, they access information using internet-based media } \\
\text { using their smartphones and laptops. The search engines they } \\
\text { often use are google search and yahoo search for reasons that } \\
\text { are easily accessible, the available sources of information are } \\
\text { many and varied, and both are available with built-in features } \\
\text { on their smartphones. All students interviewed (100\%) had a } \\
\text { Youtube account used to upload videos, but most of the } \\
\text { videos were not related to coursework or learning. Books are } \\
\text { the second media they access after accessing internet-based } \\
\text { information. Students rarely access newspapers, magazines, } \\
\text { and television to get information, especially lecture } \\
\text { assignments. }\end{array}$ \\
\hline \multirow[t]{2}{*}{$\begin{array}{l}\text { Analyze } \\
\text { media }\end{array}$} & $\begin{array}{l}\text { Understand the intended } \\
\text { use of the media }\end{array}$ & $\begin{array}{l}\text { All students }(100 \%) \text { have understood the purpose of using } \\
\text { media. Students access the media for various purposes. The } \\
\text { main goal is to find information or material related to college } \\
\text { assignments, get data about celebrity gossip, get the latest } \\
\text { news, and entertain soccer matches' video streaming. }\end{array}$ \\
\hline & $\begin{array}{l}\text { Understand the intended } \\
\text { use of the media }\end{array}$ & $\begin{array}{l}\text { Students always identify the sender of messages in the media. } \\
\text { Still, to know (40\%), students think the sender's identity is } \\
\text { useful in including it in the reference list }(60 \%) \text {. Students } \\
\text { have accessed more than one media to test the information's } \\
\text { correctness, such as viewing the internet, TV news, and } \\
\text { accessing Youtube. All students }(60 \%) \text { admitted that they }\end{array}$ \\
\hline
\end{tabular}


Test the correctness of different messages in the media

Students can understand the values and perspectives of the media.

Students understand the influence of the media.

Students can interpret media messages.
Creating/c reating media had not accurately tested a media message's truth. They claimed to have more confidence in the information broadcast through television media because it was verified before broadcast.

Some students (80\%) have not been able to judge whether messages in a media contain false information (hoaxes) or not before a body states that the data is fake (Hoax). Able students $(20 \%)$ assess a media's message as a hoax by identifying people's responses in the comments column and comparing it with messages on other media, especially television shows. All students (100\%) admitted that they understood the good and bad grades of letters on the media by looking at the message content and its words. Students rated poorly on media messages that contained provocative content, offending certain racial traits, pornography, and gambling.

All students (100\%) understand that messages in the media can influence a person's lifestyle, starting from clothes, behavior, and beliefs. As many as $20 \%$ admitted to having accessed pornographic content through the media.

As many as $100 \%$ of students could relay messages in the media after reading or watching them to other people such as friends. Students admit that it is easy to convey news messages, gossip, and entertainment. However, it is challenging to share messages containing subject matter because the lesson messages are quite tricky and consider the consequences if the message is wrong. They also think it has not become a habit/habit to convey messages of subject matter outside of class hours. They consider lecture material to be less attractive to access and report back to others.

All students (100\%) understand that there are ethics and rules in media access, but all admit that they have never studied them specifically. They are only limited to hearing from various news after violating the law regarding access to and using the media. In practice, all students never use the media to disseminate information that causes hostility to specific groups of people based on SARA, gambling, pornography, gambling, and violence. As many as $20 \%$ of students admitted to having accessed and used media containing pornographic content. All students claim to have accessed and used someone's data (friends and siblings) on electronic media such as WhatsApps (WA) without the account owner's permission to extract specific information. $60 \%$ of students also claimed to have added content such as status updates to a friend's WA account with the aim of fun or funny.

Students can apply a All students (100\%) claim to use smartphones for voice fundamental recording, taking, and simple video editing using the Viva understanding of ethical and legal issues when accessing and using media. $60 \%$ of students admit that they cannot use image editing applications to edit images/photos. As many as $40 \%$ of students claim to have been able (in high school) to create and edit images using a computer through applications such 
as Corel Draw and Photoshop, but at this time, the ability is unknown.

understand and utilize appropriate media creation tools, characteristics, and conventions
- As many as $100 \%$ of students claim to create audio media (recordings), create visual media by taking pictures/photos via cellphones and digital cameras, but have not been able to create poster and chart paintings as media. They prefer to use chapters that are already on the internet and then print them out to learn.

- As many as $100 \%$ of students admit that they have not created a film, comic, and three-dimensional model to convey learning messages.

The results showed that access media, especially internet-based media for biology teacher candidates, was in the perfect category with the highest score (Fig. 4) compared to other media literacy aspects. Media access time by students is also relatively high. On average, students access the media every day for 4.46 hours on weekdays and access the media for longer during holidays, namely an average of 7.56 hours/day. This shows that the media has become a primary need for students. Students have a high dependence on finding information through the media, especially the internet [10]. The media most accessed by students are smartphones and laptops connected to internet services. The results of the interview stated that the internet was beneficial in providing various kinds of information. As reported in previous research, it shows that perceived usefulness positively affects internet use among college students. A person will use technology (internet) if the technology provides positive results for its users [13]. The ability to access media is a must in today's era of communication technology development. A person who is unable to access media, especially internet-based media, will miss information. Prospective teacher students as agents of change have curious characteristics and access the media to update information.

Using media as a means of learning, communication and entertainment are the top three media access goals by biology teacher candidate students (Fig. 4). This study's results are consistent with the research reported by Daeng et al. (2017) regarding the use of smartphones in Manado Fispol Unstrat students that students use smartphones to support their learning [5]. Through smartphones, students can easily access the internet to get information that develops anywhere and anytime quickly. Also, smartphones can store various types of files/documents that support study/lecture activities. The research results are similar in that FISIP Mulawarman students often access the media for communication and entertainment purposes [7]. This is possible because communication can be done to reduce saturated, stressful (stressful) conditions. A person who is in a state of stress and anxiety will spend more time on his smartphone to be free from feelings of depression and anxiety [6]. Students will also feel anxious if they don't access the media for a day, especially smartphones. This study's results are supported by research that states a relationship between student anxiety and addiction to media, especially smartphones [16].

Ability to test the truth of a media message. The questionnaire results showed that the ability to test the validity of media messages by prospective teacher students was in a good category (Fig. 1). Different products were delivered from the interviews results that all students stated 
that they could not test the truth of media messages before there were parties who said that information was fake or Hoax (Table 3). Students have made efforts to try the fact by looking for the same information in various media. Still, a Hoax is a lie that is deliberately created and disseminated through internet media irresponsibly [15]. This hoax news can not only mislead prospective biology teacher students but society in general. Hoax news is prepared to create hatred, anxiety, suspicion, confusion, and the critical point that it can divide the nation's unity and integrity. The ability to test the correctness of messages in the media is not easy, especially now that every individual who has internet services can become a publisher who produces/creates information messages and disseminates news through internet-based media. This ability is important for prospective teachers. They hope that when presenting the material as teaching material to students, it does not contain false news or information that can profoundly impact students' attitudes, behavior, and even beliefs. The ability to test the truth of media messages is still low due to a lack of knowledge about official websites and hoax news spreading sites, lack of knowledge about ethics, editorial provisions in carrying out journalistic duties [4]. The absence of socialization on how to identify hoax news and how to respond to it in the Biology education study program can cause such student ability. One of the efforts that can be made is the effort to prevent hoax news through a hoax detection application [15] such as the TurnBackHoax.id mobile application designed by Mastel (Indonesian Telecommunications and Informatics Society) and published in a press release from the Ministry of Communication and Informatics [4].

Ability to judge media messages. The results showed that the ability to assess media messages was in a good category based on the questionnaire results (Fig. 1) and the results of the interviews (Table 3). Setting media messages is the ability to judge the merits of media messages from various points of view. This ability is essential considering that adolescents, including students, recognize outside life and get socialization of the values adopted by society through the reality they see and learn through the media [7]. Students identify the pros and cons of a message through construction, such as the words used in the news and the content of the message.

Ability to understand media influences. The results showed that the understanding of media influences on biology teacher candidate students was in a good category based on the questionnaire results (Fig. 1) and the results of the interviews. Students understand and feel for themselves the media's influence on lifestyles, such as the way they dress, behavior, and beliefs. Models of artists influence how young people dress in a film or specific advertising models that they see on television and social media. They are aware of the positive influence and negative influence of media messages. Students admit that they often neglect or postpone worship such as prayers due to being too busy accessing social media. This shows that the media can be said to be a "new religion." Islam as a religion is still adhered to. The behavior of daily life has always been heavily influenced by the media, such as making the media (social media) a place to complain about happiness and problems in life through the statuses that are made. Whether we realize it or not, this dependence on media is like a religious person and has become the media as its "new religion" [18].

The ability to interpret media messages in either category is based on questionnaires (Figure 1) and interviews (Table 3). The interviews showed that students easily interpreted media messages containing news and entertainment messages and communicated them back to friends. However, students have difficulty interpreting media messages and relaying them to friends if their statements are related to lesson messages. This is presumably because the lesson's announcement is not considered attractive, so it does not motivate students to access and learn it. Motivation, interest, and insufficient attention to learning messages in a medium will also 
have a low impact on understanding and interpretation skills, so that message materials tend to be slower to be conveyed to other people [2].

The ability to understand ethics around the access and use of media for prospective teacherstudents is in a good category based on a questionnaire's results (Figure 1). Different results were obtained from the effects of interviews. Students were able to mention various ethics and rules in access to and use of media, but they had not been implemented significantly. Students dare to take action to open social media accounts and other people's media devices without permission by adding and or reducing the content in them. This is presumably because students are still limited to having only heard of but have never studied the Law on Electronic Information and Transactions (ITE Law). Ethics in accessing the media as part of media literacy in education is vital considering that Indonesia has passed laws and regulations governing electronic transactions and imposing sanctions for people who misuse information media to harm others or take action against the law [1].

Ability to utilize tools, characteristics, and appropriate media creation conventions in both categories based on the questionnaire results (Fig. 1) and the results of the interviews (Table 2). However, creating media effectively is insufficient (Fig. 1) and an inadequate category (Table 3 ). The ability to create media is related to the production and distribution of media messages and critical communicative competencies for prospective teachers. Students can use various image and video editing applications to convey news, including learning letters. They knew this in high school. They only applied it through lecturers' assignments in specific subjects such as practicum courses, learning media, entrepreneurship, environmental knowledge, and educational management. All students admit that they have not created posters, charts, threedimensional media/models, and make films to messages. As many as $60 \%$ of students admitted that they had used charta in their teaching microteaching courses, the charts used were not selfmade but borrowed from the laboratory. Similar results have been reported that Communication Science study program students' ability is still low or far from what was expected [7].

The current media literacy controlled by prospective teacher students can indicate that learning in the Biology Education Study Program has not led to media literacy provision. The absence of unique courses that teach about media literacy demands that every lecturer who teaches specific courses must equip students with media literacy skills. This is due to media literacy as an essential skill for students to master to achieve a successful life in the 21 st Century [17]. Apart from learning at school or campus, several factors can influence a person's mastery of media literacy, namely the introduction of media for the first time, the person who introduced the press, the rules for using media (internet) from parents, internet access times and frequently visited internet sites [10].

The ability to access media is classified as useful, but analyzing media and creating media is still not as expected. Several ways can be done as a follow-up to the results of such research, such as 1) raising awareness of the positive and negative impacts of media use through class discussions and regular discussions as a forum for sharing and brainstorming related to media, especially digital media, 2) providing understanding to students about the purpose of media being made, how media messages/information are made, who and why media messages were made, 3) inviting students to analyze notices that appear in media, especially online media, 4) inviting students to get used to checking the correctness of information from reliable sources 5) asking students to understand the rules and code of ethics of accessing and using the media so that students are not trapped in posting messages that are not following the regulations and can harm themselves [10].

Efforts to improve media literacy above can be made through student associations in the Study Program and lecturers. Lecturers can routinely insert them between learning certain 
subjects, either directly or indirectly, such as through assignments to students. The ability to access media that is already good is expected to be an illustration for lecturers not to hesitate to carry out learning and projects related to the use of media, especially digital media and online media such as e-learning learning and learning through social media, which has not been done much $(25 \%)$. The ability to create media for prospective teacher students who are still not expected is expected to provide input for lecturers, especially lecturers who teach media and multimedia courses to improve learning that emphasizes project-based learning, namely projects making various learning media.

\section{Conclusion}

From this study, it can be concluded that the student's high-ability can represent their ideas visually. Meanwhile, students with low-ability have not been able to express their ideas optimally. For students' verbal representation is still less, especially when writing it in text. Then for the ability of symbolic representation, students can represent symbolically and solve problems given systematically. We suggest continuing the research about how students' mathematics representations in more subjects.

\section{References}

[1] Ainiyah, N. Membangun Penguatan Budaya Literasi Media dan Informasi dalam Dunia Pendidikan. Jurnal Pendidikan Islam Indonesia. 2017; 2(1): 65-77

[2] Apriyani, D. D. Pengaruh Penggunaan Media Proyeksi Terhadap Hasil Belajar Matematika. Jurnal Formatif. 2017; 7(2) : 115-123.

[3] Badan Nasional Standar Pendidikan (BNSP). Paradigma Pendidikan Nasional Abad XXI Versi 1.0. Jakarta: BNSP; 2010. 26

[4] Budiman, A. Berita Bohong (Hoax) Di Media Sosial Dan Pembentukan Opini Publik. Pusat Penelitian Badan Keahlian DPR RI. 2017; 09(01): 2009-2012.

[5] Daeng, I. T. M., Mewengkang, N., \& Kalesaran, E. R. Penggunaan Smartphone Dalam Menunjang Aktivitas Perkuliahan Oleh Mahasiswa Fispol Unsrat Manado. E-Journal Acta Diurna. 2017; 6(2): $1-15$.

[6] Demirci, K., Akgonul, M., \& Akpinar, A. Relationship of Smartphone Use Severity With Sleep Quality, Depression, and Anxiety in University Students. Journal of Behavioral Addictions. 2015; 4(2).

[7] Fitryarini, I. Literasi Media Pada Mahasiswa Prodi Ilmu Komunikasi Universitas Mulawarman. Jurnal Komunikasi. 2016; 8(1): 51-67.

[8] Griffin, P., McGaw, B., \& Care, E. Assessment and Teaching of 21st Century Skills. Dordrecht: Springer; 2012.

[9] Kemendikbud. Permendikbud No 22 tahun 2016 tentang Standar Proses Pendidikan Dasar dan Menengah. Jakarta: KEMENDIKBUD; 2016. 5

[10] Kurniawati, J., \& Baroroh, S. Literasi media digital mahasiswa Universitas Muhammadiyah Bengkulu. Jurnal Komunikator. 2016; 8(2): 51-66.

[11] Muskania, R. T., \& Wilujeng, I. Pengembangan Pembelajaran Project Based Learning Untuk Membekali Foundational Knowledge dan Meningkatkan Scientific Literacy. Cakrawala Pendidikan. 2017; 36 (1): 34-43

[12] Pattah, S. H. Literasi Informasi : Peningkatan Kompetensi Informasi dalam Proses Pembelajaran. Khizanah Al-Hikmah. 2014; 2 (2): 117-128

[13] Sanjaya, I. Pengaruh Rasa Manfaat dan Kemudahan terhadap Minat Berperilaku (Behavioral Intention) Para Mahasiswa dan Mahasiswi dalam Penggunaan Internet. Kinerja Journal of Business and Economics. 2005; 9(2): 113-122. 
[14] Scot, C. The Futures of Learning 1: Why Must Learning Content and Methods Change in The 21st Century? Paris: Education Research and Foresight; 2015.

[15] Sinaga, C. P. J., \& Yonatia, J. Kampanye Penangkalan Hoax Melalui Aplikasi Gawai. Serat Rupa Journal of Design. 2018; 2(2): 119

[16] Thomas, N. G., Kandou, G. D., \& Langi, F. L. F. G. 1 hubungan antara kecemasan dengan adiksi smartphone pada mahasiswa fakultas kesehatan masyarakat universitas sam ratulangi manado. Jurnal Kesmas. 2019; 8(2): 1-6.

[17] Trilling, Bernie, and Fadel, C. 21st Century Skills: Learning for Life in Our Times. San Francisco: John Wiley \& Sons; 2009.

[18] Wahyuni, D. Agama Sebagai Media dan Media Sebagai Agama. JIA. 2017; 5(1): 83-91

[19] Zubaidah, S. Keterampilan Abad Ke-21: Keterampilan yang Diajarkan Melalui Pembelajaran. Seminar Nasional Pendidikan. 2016; 21(2): 1-17. 